\title{
Determination of Iron (II) in some drugs as Vitamins based on lon-Selective Electrode
}

\author{
Sabah M. Moltazem ${ }^{\# *}$,Ragda R.Mohammed^ and Reem M. Allqarni ${ }^{\ell}$ \\ \#Assistant Prof. of Analytical and Inorganic Chemistry Faculty of Science Besha University Kingdam of Saudia Arabia \\ ^Master of Pharmaceutics, Faculty of Pharmacy, University of Science and Technology,Cairo,Egypt \\ ${ }^{\ell}$ Master of Analytical Chemistry Faculty of Science Besha University Kingdam of Saudia Arabia
}

Received 07 Oct 2018, Accepted 10 Dec 2018, Available online 12 Dec 2018, Vol.6 (Nov/Dec 2018 issue)

\begin{abstract}
The present work describes a sensor is composed of incorporated Rofenac $D$ as an electro active material in PVC matrix membrane and dioctylphthalate or dioctylesepacate as solvent mediators. The sensor exhibited fast and stable near Nernstian cationic response of $29.1 \pm 0.5 \mathrm{mV}$ Concentration decade of iron (II) in the concentration range of $1.0 \times 10^{-7}$ $1.0 \times 10^{-2} \mathrm{M}$. The lower limit of detection was $1.5 \times 10^{-7} \pm 0.2$. It is to be noted that the sensor based on Rofinac $D$ was used throughout this investigation in the $\mathrm{pH}$ range 3-8.5. The sensor displayed a good selectivity for iron ion respect to a number of common foreign inorganic and organic species spatially some drugs which contains iron. The results obtained with this procedure were compared with those from atomic absorption and spectrophotometry.
\end{abstract}

Keywords: Rofenac D, Foreign inorganic etc.

\section{Introduction}

Iron, one of the most abundant metals on Earth, is essential to most life forms and to normal human physiology. Iron is an integral part of many proteins and enzymes that maintain good health. In humans, iron is an essential component of proteins involved in oxygen transport [1, 2]. It is also essential for the regulation of cell growth and differentiation [3, 4]. A deficiency of iron limits oxygen delivery to cells, resulting in fatigue, poor work performance, and decreased immunity [1, 5-6]. On the other hand, excess amount of iron can result in toxicity and even death [7]. Almost two-thirds of iron in the body is found in haemoglobin, the protein in red blood cells that carries oxygen to tissues. Smaller amounts of iron are found in myoglobin, a protein that helps supply oxygen to muscle, and in enzymes that assist biochemical reactions. Iron is also found in proteins that store iron for future needs and that transport iron in blood. Iron stores are regulated by intestinal iron absorption $[1,8]$. With only a few possible exceptions in the bacterial world, there will be no life without iron [9]. If the iron concentration exceeds the normal level in the body, it may become a potential health hazard. There is considerable potential for iron toxicity because very little iron is excreted from the body. Thus, iron can accumulate in body tissues and organs when normal storage sites are

*Corresponding author's ORCID ID: 0000-0000-0000-0000 DOI: https://doi.org/10.14741/ijmcr/v.6.6.17 full. For example, people with hemachromatosis are at risk of developing iron toxicity because of their high iron stores. Excess amounts of iron ions in the body cause liver and kidney damages. Some iron compounds are realized to be carcinogenic. Hence, the need to iron ion determination in clinical, medicinal, environmental and different industrial samples has created several methods to measure this analyte [10-15].

Among analytical available techniques, the carrier based ion selective electrodes are well established analytical tools that can be used to measure different ions with the most important properties such as high speed and non-destructive sample analysis, portability of the device, online monitoring, cost effectiveness and large measuring range. A number of methods are available today to measure ion-ionophore formation constant. In some cases, a good correlation between selectivity coefficients and the ratio of experimental formation constants obtained in ordinary polar solvents has been Iron(III) ion selective electrode 116 observed [16]. However, most ion carriers form very weak complexes in such solvents [17] and most ionophores cannot be characterized with this approach. Therefore, a direct measurement of complex formation constants within the solvent polymeric membrane phase has been shown to yield more meaningful results [18].

Iron(II) is a constituent of hemoglobin which is essential for the normal transportation of oxygen to the tissues. In the foods ingested during a day, approximately 
10-15 $\mathrm{mg}$ of iron is present and studies indicate that normal subjects absorb ten per cent of iron in the food [19]. The absence of iron in the organism causes anemia, the result is of decreased red blood cell content. This deficiency is treated with iron salts via oral or intramuscular $\{20\}$ ministration. The excess of iron during treatment with iron salts may produce severe poisoning, causing symptoms of gastric irritation, vomit, pallor and circulatory collapse [21].

Liquid membrane ion-selective electrodes (ISE) in particular have much importance for the analysis of pharmaceutical products. The relatively low cost, high simplicity, selectivity and low analysis time are advantages of using ISE compared with tedious procedures suggested in the pharmacopeias $[22,23]$.

Rofenac D Tablet is used for Back pain, Sprains and strains, Dental and minor surgery, Osteoarthritis, Frozen shoulder, Dislocations and fractures, Rheumatoid arthritis, Bone and joint surgery, Acute gout, Soft tissue sports injuries, Ankylosing spondylitis, Tendonitis and other conditions. Rofenac D Tablet may also be used for purposes not listed in this medication guide.

Rofenac D Tablet contains Diclofenac Sodium as an active ingredient and works by reducing the substances in the body that cause inflammation and pain $[24,25,26,27]$.

\section{Experimental}

\subsection{Apparatus}

All potentiometric measurements were carried out at $25 \pm 0.2{ }^{\circ} \mathrm{C}$ with an Orion digital $\mathrm{pH} / \mathrm{mV}$ meter (Model SA720) using the PVC membrane sensors in Conjunction with an Orion $\mathrm{Ag} / \mathrm{AgCl}$ double junction reference electrode (Model 90-02) filled with $10 \%(\mathrm{w} / \mathrm{v}) \mathrm{KNO}$. A Combination Ross glass-pH electrode (Orion 81-02) was used for $\mathrm{pH}$ measurements. The cell used for EMF measurements is of the type: $\mathrm{Ag} / \mathrm{AgCl} / \mathrm{KCl}(0.1$ $\mathrm{M})$ /sample test solution //sensor membrane //internal filling solution $/ \mathrm{AgCl} / \mathrm{Ag}$. The potential readings of stirred $10^{-2} \mathrm{M}-10^{-7} \mathrm{M}$ working solutions were measured, recorded after stabilization to $\pm 0.5 \mathrm{mV}$ and a calibration graph was constructed.

\subsection{Reagents and solutions}

All chemicals were of analytical grade and all solutions were prepared with de-ionized water. High molecular weight poly (vinyl chloride) powder (PVC) of molecular mass of 100,000, tetrahydrofuran (THF), dioctylphthalate DOP, dioctylsebacate DOS and orthonitrophenyl octylether (o-NPOE) were purchased from FlukaChemika-Biochemika (Ronkonkoma, NY). A stouk solution $\left(10^{-1} \mathrm{M}\right)$ of potassium iodide was prepared by dissolving $1.66 \mathrm{~g}$ of potassium iodide in $100 \mathrm{ml} \mathrm{H} 2 \mathrm{O}$. The solution $\mathrm{pH}$ was adjusted with phosphate or acetate buffer to $\mathrm{pH} 4.5$ Dilute solutions of $\left(1.0 \times 10^{-2}-1.0 \times 10^{-7}\right.$ $\mathrm{M})$ were freshly prepared by diluting the stock solution with doubly distilled water and phosphate or acetate buffer of $\mathrm{pH}$.

\section{$2.3 \mathrm{pH}$ effect}

The effect of $\mathrm{pH}$ on the response of the iron(II) electrode determined using A Ross glass-pH electrode (Orion model 81-02) used for all $\mathrm{pH}$ measurements and Orion digital $\mathrm{pH} / \mathrm{mV}$ model(90-02) meter $\mathrm{Ag} / \mathrm{AgCl}$ double junction reference electrode was used for potentiometric measurements.

\subsection{The response}

Stable potentials were achieved within a few seconds (less than $5 \mathrm{~s}$ ) and the relative standard deviation of 10 identical measurements was less than $3 \%$ for a solution containing $5.0 \times 10-3 \mathrm{~mol} / \mathrm{L}$ iron(II).

This electrode presented a useful lifetime of at least six months (more than 800 determinations/polymeric membrane) without significant loss in sensitivity.

The response time of sensor was determined by measuring the potential response as a function of time for various Concentration of Fe2+ions $\left(10^{-2}-10^{-6} \mathrm{M}\right)$, and the results were plotted.

\subsection{Sensor of Iron (II)}

\subsubsection{Sensor Construction}

Iron responsive membrane sensor was prepared as described previously (28) by mixing $0.01 \mathrm{gm}$ ionophore (ROFINAC D, Fig 3-1), $\quad 0.35 \mathrm{gm}$ DOS plasticizer and 0.19 gm PVC.The mixture was dissolved in $0.35 \mathrm{ml}$ THF in a glass Petri dish ( $3 \mathrm{~cm}, 4 \mathrm{CM}$ diameter), Covered with a filter paper and left to stand overnight to allow slow evaporation of the solvent at room temperature. Disks $(0.7 \mathrm{~mm}$ diameter) were cut out from the parent membrane and mounted in the PVC electrode body (0.6 $\mathrm{mm}$ diameter) using THF and repeating this with DOP and ortho- nitrophenyl octylether(o-NPOE) . A mixed solution Consisting of equal volumes of 10-3 M IRON nitrate and 10-3 $\mathrm{M} \mathrm{KCl}$ was used as an internal reference solution and $\mathrm{Ag} / \mathrm{AgCl}$ Coated wire (3 $\mathrm{mm}$ diameter) was employed as an internal reference electrode. The sensor was Ccnditioned by soaking overnight in a solution of 10-2 M Iron nitrate and stored in the same solution when not in use.

\subsubsection{Sensor calibration}

The sensors were calibrated by transferring $10 \mathrm{ml}$ aliquots of 10-2 $\mathrm{M}$ to 10-7 $\mathrm{M}$ aqueous iron solution to the $50 \mathrm{ml}$ double walled-glass cell. The potential readings were recorded after stabilization (to $\pm 0.2 \mathrm{mV}$ ) and plotted as a function of logarithmic Concentration of Iron. The calibration graphs were used for subsequent determination of unknown Iron Concentration. 
2.6 Analytical Applications and Instrumental megerment of sensor

Determination iron(II) in some drugsas (vitamin) formulation samples. The results are was compared with those obtained by atomic absorption and spectrosphotometric methods Which was measured in the laboratory of micro analytical at the University of Cairo and King Khalid University in Saudi Arabia

\section{Results and Discussion}

\subsection{Characteristics of the Iron sensor}

The most important characteristics of any ion-sensitive sensor are its response to the primary ion (Iron ions) in the presence of other ions in the solution. This is expressed in terms of the potentiometric selectivity coefficient.

In this work, the ligand (Rofinac D) used as an ionophore in the Iron ion-selective electrode should fulfil certain conditions. It should be selective for Iron ion over other metal cations, and it should have rapid exchange kinetics and be sufficiently lipophilic to prevent leaching of the ligand into the aqueous solution surrounding the membrane electrode [29]. this ligand was expected to act as a suitable ion carrier in the PVC membrane sensors. Thus, ROFINAC D was used, in the primarily experiments, as a neutral carrier to prepare polymeric membrane electrodes for a variety of Iron ions<smiles>O=C(O)Cc1ccccc1Nc1c(Cl)cccc1Cl</smiles>

Fig 3.1 Chemical formula of Rofinac D

\subsection{Effect of plasticizer}

A different plasticizers have been used in this work as DOS , DOP and (O-NPOE). with Iron membrane electrodes based on Rofinac D is represented in Fig. (3.2). It is noteworthy that the lipophilicity of the plasticizer influences both the dielectric Constant of the polymeric membranes and the mobility of the ionophore. It is clear from Fig. (3.2) that all of them have exactly the same effect with very slight difference.

The performance characteristics of the sensor were evaluated under many different variables such as plasticizers, and the influence of $\mathrm{pH}$. The results obtained are summarized in Table (3.1). The data show that the proposed sensor is highly selective and sensitive with respect to $\mathrm{Fe}^{2+}$ ions, and this is appeared in the values, of the slope (which obeys Nernst equation), the lower limit of detection and the wide linear range.

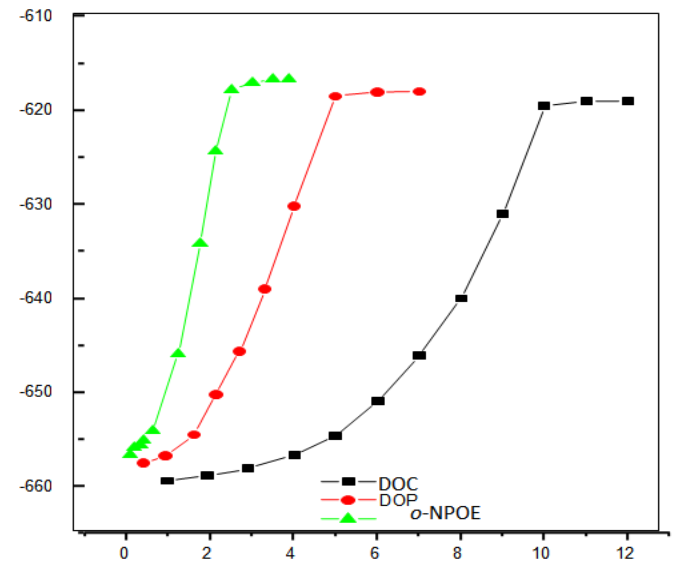

Fig. 3.2 Potentimetric response curves of the proposed sensor with different plasticizers

Table 3.1: Response characteristics of the Rofinac D PVC Iron sensor

\begin{tabular}{|c|c|c|c|}
\hline \multirow{2}{*}{ Parameter } & \multicolumn{3}{|c|}{ Value } \\
\cline { 2 - 4 } & DOS & DOP & (o-NPOE). \\
\hline Slope (mv, decade) & 29.7 & 29.5 & 29.8 \\
\hline Linear range (M) & $\begin{array}{c}1.00 \times 10^{-7}- \\
1.00 \times 10^{-2}\end{array}$ & $\begin{array}{c}1.5 \times 10^{-6}- \\
1.00 \times 10^{-2}\end{array}$ & $\begin{array}{c}1.2 \times 10^{-7}- \\
1.00 \times 10^{-2}\end{array}$ \\
\hline Detection limit (M) & $1.5 \times 10^{-7}$ & $1.2 \times 10^{-6}$ & $1.5 \times 10^{-7}$ \\
\hline Intercept (mv) & 511 & 491 & 495 \\
\hline pH range & $3.9-8.5$ & $4-8.2$ & $3.8-8.3$ \\
\hline Response time (sec) & $21 \geq$ & $25 \geq$ & $22 \geq$ \\
\hline Accuracy (\%) & 98 & 97 & 98 \\
\hline Standard deviation (\%) & \pm 0.3 & \pm 0.4 & \pm 0.3 \\
\hline CurrelationCuefficient (T) & 0.999 & 0.999 & 0.999 \\
\hline
\end{tabular}

\subsection{Potentiometric selectivity}

The selectivity is the most important characteristic of any sensor, which defines the extent to which it may be used to selectively estimate a particular ionic species likely to be present in actual samples along with other species to be determined. The potentiometric selectivity Coefficients were experimentally determined in which the cell potential was measured for the same Concentration ( $a \mathrm{i}=\mathrm{aj}=1.0 \times 10^{-3} \mathrm{M}$ ) of the primary ion solution and the interfering ion solution separately. The obtained cell potential for interfering ions and the analyte ions ( $\Delta \mathrm{Ej}$ and $\Delta \mathrm{Ei}$, respectively) are inserted into the following equation to calculate the selectivity Coefficient, log Ki,jpot .

$\log \mathrm{K}_{\mathrm{ij}}^{\mathrm{pot}}=\frac{\left(\Delta \mathrm{E}_{\mathrm{j}}-\Delta \mathrm{E}_{\mathrm{i}}\right) \mathrm{Z}_{\mathrm{i}} \mathrm{F}}{2.303 \mathrm{RT}}$

Where Zi: charge of the primary ion, R: Molar gas Constant, 


\section{T: absolute temperature and}

F: Faraday's Cunstant (96487 cal mole-1).

The results obtained are summarized in Table (3.10) it Could be shown that the selectivity of the proposed sensor towards iorn is more than a large number of Inorganic cations, such as $\mathrm{Na}^{+}, \mathrm{K}^{+}, \mathrm{Ca}^{2+}, \mathrm{Mg}^{2+,} \mathrm{CU}^{2+}$, etc. Also Comparing the selectivity Coefficient of the Considered sensor with of different electrodes shows that the proposed sensor has a good response to Iron ions over a number of other electrodes as given in Table (3.2).

Table 3.2: Potentiometric selectivity Coefficients of ketofan membrane sensor

\begin{tabular}{|c|c|}
\hline Interfering lon & $\log K_{\mathrm{Co}++, B}^{P O T}$ \\
\hline $\mathrm{Fe} 2+$ & -4.59 \\
$\mathrm{CO}^{3+}$ & -3.10 \\
$\mathrm{Cu} 2+$ & -2.90 \\
$\mathrm{Al} 3+$ & -2.73 \\
$\mathrm{Na}+$ & -2.69 \\
$\mathrm{Ag}+$ & -2.49 \\
$\mathrm{NH} 4+$ & -3.16 \\
$\mathrm{Ba} 2+$ & -2.18 \\
$\mathrm{~K}+$ & -2.28 \\
$\mathrm{Ni2}+$ & -2.15 \\
$\mathrm{Mg} 2+$ & -1.53 \\
$\mathrm{Sr} 2+$ & -1.46 \\
$\mathrm{Cd} 2+$ & -1.33 \\
\hline
\end{tabular}

\subsection{Effect of $\mathrm{pH}$}

The $\mathrm{pH}$ dependence of the electrode potential is plotted over the $\mathrm{pH}$ range of $2-10$ for $1.0 \times 10-2$ and $1.0 \times 10-3 \mathrm{M}$ $\mathrm{Cu}$ (II) ions solutions in Fig. (3.30). the $\mathrm{pH}$ of the solutions was adjusted by the addition of small drops of HNO3 (0.1 $\mathrm{M})$ and $\mathrm{NaOH}(0.1 \mathrm{M})$. It is clear from the figure that the useful range is 4-8.5 because the potential remains Constant at this range. The sharp change in potential at higher $\mathrm{pH}$ values may be due to the formation of some hydroxy Complexes of $\mathrm{Fe}^{2+}$, while at lower $\mathrm{pH}$ values $\mathrm{H}_{3} \mathrm{O}^{+}$ ions may start to contribute to the charge transport process by the membrane, thereby causing interference.

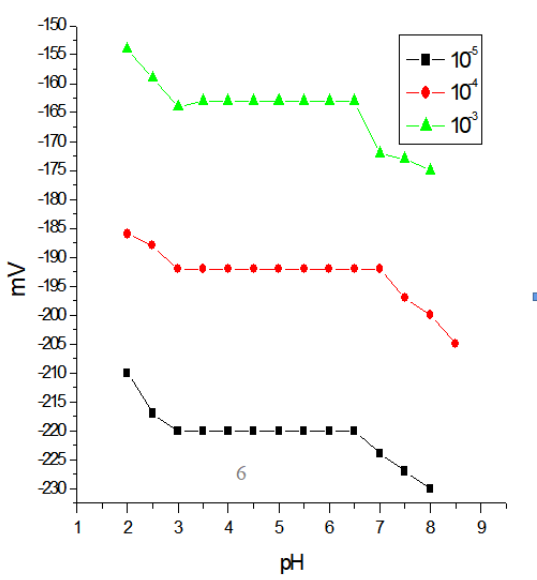

Fig 3.3 Effect of $\mathrm{pH}$ on the potential response of the proposed sensor

\subsection{Response time}

The optimum response time for the membrane electrode in $1.0 \times 10-1 \mathrm{M} \mathrm{Cu}^{2+}$ solution was found to be after 4 times when its starts generating stable potential. The response time of the electrode was determined by measuring the time required to achieve $90 \%$ of the steady potential. The static response time thus obtained was 18 $20 \mathrm{sec}$ over the entire Concentration range Fig. (3.3).

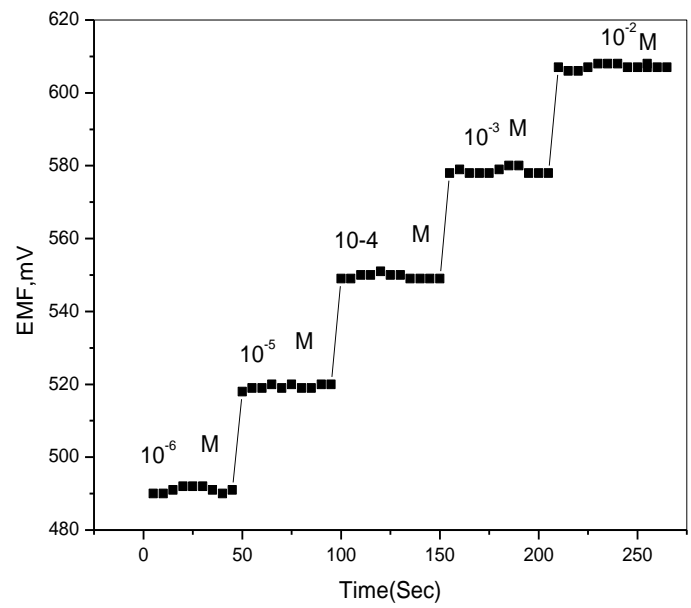

Fig 3.3 Dynamic response time of the sensor

\subsection{Applications}

3.7.1. Determination of Iron in some drugs samples which contains it as Neurobion Ampoules, Ferrotron Capsules, HemAmax and Complete Gest with potentiometrically using the proposed sensor and a standard method (AAS).After comparison we found that the lorn Contents obtained from triplicate measurements using potentiometric measurement are in a satisfactory agreement with those obtained by using the AAS method. Thus, the electrode provides a good alternative procedure for the determination of $\mathrm{Fe} 2+$ in real samples. The results are given in Table (3.3).

Table 3.3: Determination of Iorn (II) in some Drugs samples with the sensor, and AAS

\begin{tabular}{|c|c|c|}
\hline Sample & Potentiometrically (mg1-1) & AAS (mg 1-1) \\
\hline $\begin{array}{c}\text { Neurobion } \\
\text { Ampoules }\end{array}$ & $25 \pm 0.2$ & $25 \pm 0.5$ \\
\hline $\begin{array}{c}\text { Ferrotron } \\
\text { Capsules }\end{array}$ & $26 \pm 0.1$ & $25 \pm 0.8$ \\
\hline HemAmax & $24 \pm .02$ & $25 \pm 0.9$ \\
\hline Complete Gest & $26 \pm 0.4$ & $26 \pm 0.4$ \\
\hline
\end{tabular}

\section{References}

[1]. DC. National Academy Press, 2001.

[2]. P.R. Dallman, Annu. Rev. Nutr. 6: (1986) 13-40.

[3]. T.H. Bothwell, R.W. Charlton, J.D. Cook, C.A. Finch, St. Louis: Oxford: Blackwell Scientific, 1979. 
[4]. N.C. Andrews, N. Engl. J. Med. 341 (1999) 1986-1995.

[5]. J.D. Haas, T. Brownlie, J. Nutr. 131 (2001) 691S-6S.

[6]. P. Bhaskaram, Br. J. Nutr. 85 (2001) S75-80.

[7]. J.V. Corbett, Am. J. Matern. Child. Nurs. 20 (1995) 234.

[8]. S. Miret, R.J. Simpson, A.T. McKie, Annu. Rev. Nutr. 23 (2003) 283-301.

[9]. N.N. Greenwood, A.E. Haw, Chemistry of the Elements, Pergamum Press, Oxford, 1984, p. 1243.

[10]. A.F. Oliverra, J.A. Nobrega, O. Fatibello-Filho, Talanta, 49 (1995) 505-510.

[11].J.M.T. Carneiro, A.C.B. Dias, E.A.G. Zagatto, R.S. Honorato, Anal. Chim. Acta, 455 (2002) 327-333.

[12]. A. Safavi, H. Abdollahi, M.R. Hormozi-Nezhad, Talanta, 56 (2002) 699-704.

[13]. B. Nagabhushana, G. Chandrappa, B. Nagappa, N. Nagaraj, Anal. Bioanal. Chem. 373 (2002) 299-303.

[14].J. Zolgharnein, H. Abdollahi, D. Jaefarifar, G.H. Azimi, Talanta, 57 (2002) 1067-1073.

[15]. R.C.C. Costa, A.N. Araujo, Anal. Chim. Acta, 438 (2001) 227233.

[16]. M.B. Gholivand, F. Ahmadi, E. Rafiee, Electroanalysis 18 (2006) 1620.
[17].A.K. Jain, V.K. Gupta, L.P. Singh, J.R. Raisoni, Talanta, 66 (2005) 1355.

[18]. M.R. Ganjali, R. Zare-Dorabei, P. Norouzi, Sen. Act. B, 143 (2009) 233-238.

[19].Wintrole, M. Clinical Hematology, Lea \&Febiger, Philadelphia, 1961, pp.143.

[20]. Corbett, C.E. Farmacodinâmica, Guanabara Koogan, Rio de Janeiro, 1977, pp.490.

[21]. Musser, R.D.; O'Neil, J.J. Pharmacology and Therapeutics, The Macmillan Company, 1969, pp.547.

[22]. The United States Pharmacopeia 1995, pp.660.

[23]. Bristish Pharmacopeia 1980, v. 2, pp.559.

[24]. NHS Choices. What should I do if I miss a dose of antibiotics? - Accessed: July 14, 2016.

[25]. Ever Miss a Dose of Your Medicine?-Accessed: July 3, 2016.

[26]. Cancer.Net (2014). The Importance of Taking Your Medication Correctly - Accessed: July 3, 2016.

[27].Schachter, S.C., Shafer, P. O. \&; Sirven, J.I. (2013). Missed Medicines. Epilepsy Foundation - Accessed: May 28, 2016

[28]. Hassan S.S.M., Mahmoud W.H., Othman A.M., Talanta 47 (2003) 377

[29]. Gupta V.K., Prasad R., Kumar A., Talanta 60 (2003) 149. 